\title{
Antiangiogenic and anticolorectal cancer effects of metronomic irinotecan chemotherapy alone and in combination with semaxinib
}

\section{G Bocci",', A Falcone', A Fioravanti', P Orlandi', A Di Paolo', G Fanelli ${ }^{3}$, P Viacava ${ }^{3}$, AG Naccarato ${ }^{3}$, RS Kerbel ${ }^{4,5}$, R Danesi', M Del Tacca' ${ }^{1}$ and G Allegrini ${ }^{2}$}

'Division of Pharmacology and Chemotherapy, Department of Internal Medicine, University of Pisa, Pisa, Italy; ${ }^{2}$ Division of Medical Oncology, General Hospital of Livorno, Department of Oncology, University of Pisa, Pisa, Italy; ${ }^{3}$ Division of Surgical, Molecular and Ultrastructural Pathology, Department of Oncology, University of Pisa, Pisa, Italy; ${ }^{4}$ Molecular and Cellular Biology Research, Sunnybrook Health Sciences Centre, Toronto, Ontario, Canada;

${ }^{5}$ Department of Medical Biophysics, University of Toronto, Toronto, Ontario, Canada

\begin{abstract}
Metronomic chemotherapy refers to the administration of chemotherapy at low, nontoxic doses on a frequent schedule with no prolonged breaks. The aim of the study is to rationally develop a CPT-I I metronomic regimen in preclinical settings of colon cancer. In vitro cell proliferation, apoptosis and thrombospondin- I/vascular endothelial growth factor (TSP- I/VEGF) expression analyses were performed on endothelial (HUVEC, HMVEC-d) and colorectal cancer (HT-29, SW620) cells exposed for I44h to metronomic concentrations of $\mathrm{SN}-38$, the active metabolite of CPT-I I. HT-29 human colorectal cancer xenograft model was used, and tumour growth, microvessel density and VEGF/TSP-I quantification was performed in tumours. In vitro and in vivo combination studies with the tyrosine inhibitor semaxinib were also performed. SN-38 preferentially inhibited endothelial cell proliferation alone and interacted synergistically with semaxinib; it induced apoptosis and increased the expression and secretion of TSP-I. Metronomic CPT-I I alone and combined with semaxinib significantly inhibits tumour growth in the absence of toxicity, which was accompanied by decreases in microvessel density and increases in TSP-I gene expression in tumour tissues. In vitro results show the antiangiogenic properties of low-concentration SN-38, suggesting a key role of TSP-I in this effect. In vivo, the CPT-II metronomic schedule is effective against tumour and microvessel growth without toxic effect on mice.
\end{abstract}

British Journal of Cancer (2008) 98, 1619-1629. doi:10.1038/sj.bjc.6604352 www.bjcancer.com

Published online 29 April 2008

(c) 2008 Cancer Research UK

Keywords: metronomic chemotherapy; angiogenesis; irinotecan; semaxinib; colon cancer

The interest in exploiting chemotherapeutic drugs for their antiangiogenic properties in the context of cancer therapy has been stimulated by a number of preclinical studies, in particular the pioneering contribution of Folkman and co-workers and that of the groups of Kerbel and Hanahan (Browder et al, 2000; Klement et al, 2000; Bocci et al, 2002; Man et al, 2002; Pietras and Hanahan, 2005) using drugs such as cyclophosphamide, oral fluoropyrimidines, vinblastine or taxanes at doses much lower than the maximum-tolerated dose (MTD), administered at close regular intervals either alone or in combination with targeted antiangiogenic drugs. The metronomic chemotherapy strategy - a long-term, low-dose, frequent administration of chemotherapeutic drugs with no prolonged drug-free breaks (Kerbel and Kamen, 2004) - appears to enhance the efficacy of the antiangiogenic effects of standard chemotherapy (with lower toxic effects) and

* Correspondence: Dr G Bocci, Division of Pharmacology and Chemotherapy, Department of Internal Medicine, University of Pisa, Via Roma, 55, Pisa I-56I26, Italy; E-mail: g.bocci@med.unipi.it

Received 21 November 2007; revised 10 March 2008; accepted 26 March 2008; published online 29 April 2008 implies that activated vascular endothelial cells (Bocci et al, 2002) or circulating endothelial progenitors (Bertolini et al, 2003) may be more sensitive to low or lower doses of various chemotherapeutic drugs. Besides a direct effect on endothelial cell proliferation, protracted exposure to low concentrations of several different anticancer agents, including microtubule inhibitors and alkylating agents, can cause marked induction, in vitro and in vivo, of gene and protein expression of thrombospondin-1 (TSP-1), a potent and endothelial-specific inhibitor of angiogenesis (Sund et al, 2005), suggesting that it could be a key mediator for metronomic chemotherapy activity (Bocci et al, 2003; Damber et al, 2006; Hamano et al, 2004).

Despite abundant information about the pharmacology of irinotecan (CPT-11) (Di Paolo et al, 2006) and its active metabolite $\mathrm{SN}-38$ on cancer cells using different therapeutic approaches, no data are currently available about the preclinical effects of metronomic CPT-11 administration on pathological angiogenesis and tumour growth. O'Leary et al (1999) have described an antiangiogenic effect of CPT-11 in a single experimental setting (using a cornea model of angiogenesis), whereas Kamiyama et al (2005) reported that SN-38, at cytotoxic standard doses, inhibited both endothelial cell proliferation and tube formation, decreasing 
HIF- $1 \alpha$ and vascular endothelial growth factor (VEGF) gene expression in glioma cells under both normoxic and hypoxic conditions. However, no further preclinical studies have followed these preliminary reports evaluating possible additional mechanisms of drug action.

On the basis of this background, we decided to test, for the first time, the hypothesis that CPT-11 metronomic regimens can be effective in preclinical settings of colon cancer treatment; specifically, we investigated the in vitro and in vivo antiangiogenic/antitumour activity and the modulation of pro- (VEGF) and antiangiogenic (TSP-1) factor expression/secretion using low-dose schedules. Moreover, the effect of the simultaneous combination of irinotecan or SN-38 with semaxinib was studied both in vitro and in vivo.

\section{MATERIALS AND METHODS}

\section{In vitro studies}

Materials, drugs and cell lines Recombinant human epidermal growth factor (EGF), basic fibroblast growth factor (bFGF) and VEGF were from PeproTechEC LTD (London, UK). Cell culture media, MCDB131 and DMEM, were purchased from Gibco BRL (Paisley, UK), quantitative real-time PCR (QRT-PCR) reagents were from Applied Biosystems (Foster City, CA, USA), supplements and all other chemicals not listed in this section were obtained from Sigma Chemical Co. (St Louis, MO, USA).

SN-38 was a generous gift from Pfizer (Groton, CT, USA) and dissolved in a stock solution of $10 \mathrm{~mm}$ in $100 \%$ DMSO for in vitro studies. CPT-11 (Pfizer) was purchased from the University hospital pharmacy (Ospedale S Chiara, Pisa, Italy) and reconstituted as per the manufacturer's instructions to a stock concentration of $20 \mathrm{mg} \mathrm{ml}^{-1}$ by the addition of sterile saline for in vivo studies.

Semaxinib (SU5416) was purchased from Sigma Chemical Co. and was dissolved in $100 \%$ DMSO for in vitro use and in a solution of $99 \%$ PEG-300 (w/v) and 1\% Tween 80 for in vivo studies (Bocci et al, 2004a).

Human umbilical vein endothelial cells (HUVEC) and the human dermal microvascular endothelial cells (HMVEC-d; Clonetics, San Diego, CA, USA) were maintained in MCDB131 culture medium supplemented with $10 \%$ heat-inactivated FBS, L-glutamine $2 \mathrm{~mm}$, heparin $10 \mathrm{U} \mathrm{ml}^{-1}$, EGF $10 \mathrm{ng} \mathrm{ml}^{-1}$ and bFGF $5 \mathrm{ng} \mathrm{ml}^{-1}$. The human colon tumour cell lines HT-29 and SW620 (ATCC, Manassas, MA, USA) were maintained in 10\% FBS DMEM medium supplemented with L-glutamine $2 \mathrm{~mm}$.

Cell proliferation assay and apoptosis measurements Human umbilical vein endothelial cells, HMVEC-d, HT29 and SW620 cells were plated in 24 -well sterile plastic plates ( $1 \%$ gelatin-coated for the endothelial cells) and treated continuously for $144 \mathrm{~h}\left(1 \times 10^{3}\right.$ and $0.5 \times 10^{3}$ cells per well of normal or cancer cells, respectively, in $1 \mathrm{ml}$ of medium) with various concentrations of $\mathrm{SN}-38$ $(1-100000 \mathrm{pm})$ adding fresh solutions with new medium every $24 \mathrm{~h}$ (Bocci et al, 2002). Furthermore, to determine a timedependent effect on endothelial cell proliferation, HMVEC-d cells were exposed for $72 \mathrm{~h}$ to SN-38 (1-100000 pM). At the end of the experiments, cells were harvested with trypsin/EDTA and viable cells counted with a haemocytometre. Cell viability was assessed by trypan blue dye exclusion (Bocci et al, 2005). The data are presented as the percentage of the vehicle-treated cells. The concentration of drug that reduced cell proliferation by $50 \%\left(\mathrm{IC}_{50}\right)$ $v s$ controls was calculated by nonlinear regression fit of the mean values of the data obtained in triplicate experiments (at least nine wells for each concentration).

To quantify the degree of apoptosis induced by the drug treatments, HMVEC-d, HUVEC, HT29 and SW620 cells were continuously treated for $144 \mathrm{~h}$ with $\mathrm{SN}-38$ at a concentration corresponding to the experimental $\mathrm{IC}_{50}$ of cell proliferation $(15,200,1500$ and $650 \mathrm{pm}$, respectively) or vehicle alone. At the end of the incubation, cells were washed twice with PBS and fixed in $4 \%$ buffered paraformaldehyde for $15 \mathrm{~min}$. Cells were resuspended and incubated for an additional $15 \mathrm{~min}$ in a solution containing $8 \mu \mathrm{g} \mathrm{ml}^{-1}$ bisbenzimide $\mathrm{HCl}$ (Hsueh et al, 2000). Cells were spotted on glass slides and were examined by fluorescence microscopy (Leica, Wetzlar, Germany). A total of 100 cells from nine randomly chosen microscopic fields were counted, and the percentage of cells displaying chromatin condensation and nuclear fragmentation relative to the total number of counted cells (apoptotic index) was calculated.

In vitro assessment of synergism between semaxinib and $\mathrm{SN}-38$ on endothelial cells Semaxinib combined with SN-38 was explored on HMVEC-d cells with the simultaneous continuous exposure of semaxinib $(0.01-100 \mu \mathrm{M})$ plus SN-38 $(1-10000 \mathrm{pM})$ for $144 \mathrm{~h}$ at a fixed molar concentration ratio of $10000: 1$. To evaluate the level of interaction (synergistic, additive or antagonist) between SN-38 and semaxinib, the method proposed by Chou (2006) was followed. Briefly, synergism or antagonism for semaxinib plus SN-38 was calculated on the basis of the multiple drug-effect equation, and quantitated by the combination index (CI), where $\mathrm{CI}<1, \mathrm{CI}=1$ and $\mathrm{CI}>1$ indicate synergism, additive effect and antagonism, respectively. On the basis of the classic isobologram for mutually exclusive effects, the CI value was calculated as:

$$
\mathrm{CI}=\left[(\mathrm{D})_{1} /\left(\mathrm{D}_{\mathrm{X}}\right)_{1}\right]+\left[(\mathrm{D})_{2} /\left(\mathrm{D}_{\mathrm{X}}\right)_{2}\right]
$$

At the $50 \%$ inhibition level, $\left(D_{\mathrm{x}}\right)_{1}$ and $\left(D_{\mathrm{x}}\right)_{2}$ are the concentrations of semaxinib and $\mathrm{SN}-38$, respectively that induce a $50 \%$ inhibition of cell growth; $(D)_{1}$ and $(D)_{2}$ are the concentrations of semaxinib and SN-38 in combination, which also inhibits cell growth by $50 \%$ (isoeffective as compared with the single drugs alone).

Real-time PCR analysis of human VEGF and TSP-1 gene expression on tumour and endothelial cells To evaluate the expression of the human VEGF and TSP-1 genes, $2 \times 10^{4}$ HMVEC-d, HUVEC, HT29 and SW620 cells were grown in their respective media and treated with $\mathrm{SN}-38$ at a concentration corresponding to the experimental $\mathrm{IC}_{50}$ of cell proliferation $(15,200,1500$ and $650 \mathrm{pM}$, respectively) and at a lower and inactive dose $(1,10,10$ and $10 \mathrm{pM}$, respectively) or with vehicle alone for $144 \mathrm{~h}$. Briefly, RNA (1 $\mu \mathrm{g})$ was reverse transcribed as previously described (Bocci et al, 2005), the resulting cDNA was diluted $(2: 3)$ and then amplified by QRTPCR with the Applied Biosystems 7900HT sequence detection system. Vascular endothelial growth factor and TSP-1 validated primers were purchased from Applied Biosystems (Assay ID Hs00170236_m1 and Hs00173626_ml, respectively). The PCR thermal cycling conditions and optimisation of primer concentrations were followed as per the manufacturer's instructions. Amplifications were normalised to glyceraldehyde 3-phosphate dehydrogenase (GAPDH), and the quantitation of gene expression was performed using the $\Delta \Delta C_{\mathrm{t}}$ calculation, where $C_{\mathrm{t}}$ is the threshold cycle; the amount of target, normalised to the endogenous control and relative to the calibrator (vehicle-treated control cells), is given as $2^{-\Delta \Delta C t}$.

Human VEGF and TSP-1 detection in conditioned media by ELISA and EIA Human dermal microvascular endothelial cells, HUVEC, HT29 and SW620 cells were grown in their respective media and treated with $\mathrm{SN}-38$ at a concentration corresponding to the experimental $\mathrm{IC}_{50}$ of cell proliferation $(15,200,1500$ and $650 \mathrm{pM}$, respectively) and at a lower and inactive concentration $(1,10,10$ and $10 \mathrm{pm}$, respectively) or with vehicle alone for $144 \mathrm{~h}$. Furthermore, to determine a time-dependent effect on endothelial cell secretion, HMVEC-d cells were exposed for $72 \mathrm{~h}$ to the SN-38 
experimental $\mathrm{IC}_{50}$ of cell proliferation (13 nM). To measure secreted VEGF and TSP-1, at the end of the experiment the medium of each well was discarded and replaced with serum-free medium for $4 \mathrm{~h}$. Each sample was then assayed for human VEGF and TSP-1 concentrations by the ELISA Kit Quantikine (R\&D Systems, Minneapolis, MN, USA) and by the ChemiKine Human TSP-1 EIA Kit (Chemicon, Temecula, CA, USA), respectively, and normalised by total protein concentration. The optical density was determined using the microplate reader Multiskan Spectrum (Thermo Labsystems, Milan, Italy) set to $450 \mathrm{~nm}$ (with a wavelength correction set to $540 \mathrm{~nm}$ ) for the VEGF kit and to $490 \mathrm{~nm}$ for TSP-1 kit. All experiments were repeated, independently, six times with at least nine samples for each concentration.

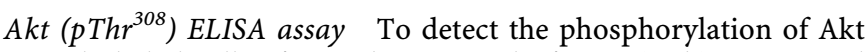
in endothelial cells after a short period of time (72 h), HMVEC-d cells were treated with $\mathrm{SN}-38$ at a concentration corresponding to the experimental $\mathrm{IC}_{50}$ of cell proliferation $(13 \mathrm{nM})$ or with vehicle alone for $72 \mathrm{~h}$. To measure pAkt, at the end of the experiment, the cells were harvested and immediately frozen with liquid nitrogen. Each sample was then assayed for human pAkt $\left(\mathrm{pThr}^{308}\right.$ ) concentrations by the ELISA Kit PhosphoDetect Akt ( $\mathrm{pThr}^{308}$ ) (Calbiochem, San Diego, CA, USA) and normalised by total protein concentration. The optical density was determined using the microplate reader Multiskan Spectrum set to $450 \mathrm{~nm}$. The results were expressed as pAKT unit per $\mathrm{mg}$ of total protein. All experiments were repeated, independently, six times with at least nine samples for each concentration.

\section{In vivo studies}

Animals CD nu/nu male mice, weighing 20-25 g, were supplied by Charles River (Milan, Italy) and were allowed unrestricted access to food and tap water. Housing and all procedures involving animals were performed according to the protocol approved by the Academic Committee for the animal experimentation of the University of Pisa, in accordance with the European Community Council Directive 86-609, recognised by the Italian government, on animal welfare. Each experiment employed the minimum number of mice needed to obtain statistically meaningful results.

HT-29 xenografts in $n u / n u$ mice and drug treatments HT-29 cell viability was assessed by trypan blue dye exclusion, and on day 0 , $1.3 \times 10^{6} \pm 5 \%$ cells per mouse were inoculated subcutaneously (s.c.) between the scapulae in $0.2 \mathrm{ml}$ per mouse of culture medium without FBS. Animal weights were monitored and upon appearance of a subcutaneous mass, tumour dimensions were measured every 2 days in two perpendicular directions using callipers. Tumour volume $\left(\mathrm{mm}^{3}\right)$ was defined as $\left[\left(w_{1} \times w_{2} \times w_{2}\right) \times(\pi / 6)\right]$, where $w_{1}$ and $w_{2}$ were the largest and the smallest tumour diameters (mm), respectively (Bocci et al, 2004b). The mice were randomised into groups of six animals. To treat an established tumour $\left(\sim 35 \mathrm{~mm}^{3}\right)$, from day 15 after cell inoculation, CPT-11 was administered i.p. as follows: (1) CPT-11 at the MTD of $100 \mathrm{mg} \mathrm{kg}^{-1}$ five times at 7-day intervals (Allegrini et al, 2004); (2) metronomic CPT-11 every day at the dose of $4 \mathrm{mg} \mathrm{kg}^{-1}$ for 50 days (a 72\% decrease vs MTD dose); (3) a sequential treatment of an initial ('up-front') single dose of CPT-11 $100 \mathrm{mg} \mathrm{kg}^{-1}$ followed by metronomic CPT-11 $4 \mathrm{mg} \mathrm{kg}^{-1}$ every day for 49 days. The control group was injected i.p. with vehicle alone (saline solution). The experimental period ended 65 days after the inoculation of tumour cells whereas control mice were killed by an anaesthetic overdose when the tumour volume reached a mean value of $3200 \mathrm{~mm}^{3}$.

To establish the antitumour activity of metronomic CPT-11 and semaxinib combination in vivo, an additional experiment was performed. On day 15, from HT-29 cell inoculum, metronomic CPT-11 schedules and their simultaneous combinations with semaxinib were administered i.p. as follows: (1) metronomic
CPT-11 every day at the dose of $4 \mathrm{mg} \mathrm{kg}^{-1}$ for 33 days; (2) an initial single dose of CPT-11 $100 \mathrm{mg} \mathrm{kg}^{-1}$ followed by metronomic CPT$114 \mathrm{mg} \mathrm{kg}^{-1}$ every day for 32 days; (3) combination treatment of CPT-11 $4 \mathrm{mg} \mathrm{kg}^{-1}$ every day and semaxinib $10 \mathrm{mg} \mathrm{kg}^{-1}$ twice weekly; (4) combination treatment of an initial single dose of CPT-11 $100 \mathrm{mg} \mathrm{kg}^{-1}$ followed by metronomic CPT-11 $4 \mathrm{mg} \mathrm{kg}^{-1}$ every day and semaxinib $10 \mathrm{mg} \mathrm{kg}^{-1}$ twice weekly. The control group was injected i.p. with vehicle alone (saline solution and PEG300/Tween 80). Animal weights were monitored as described above. Drug efficacy was based on percentage of the average treated-tumour volume divided by the average vehicle-controltumour volume (\% T/C) (Tahir et al, 2003).

Immunohistochemistry, microvessel density and real-time RT-PCR on HT-29 tumour tissue samples After surgical resection, tumour tissue samples from all the different treatment groups were split into two aliquots, one fixed in $10 \%$ phosphate-buffered formaldehyde for $12-24 \mathrm{~h}$ and embedded in paraffin for histology and immunohistochemistry, the other immediately frozen in liquid nitrogen for the analysis of human VEGF and TSP-1 gene expression by real-time RT-PCR.

Five-micrometre sections were stained with haematoxylineosin for histological analysis. Adjacent sections were cut for immunohistochemistry as previously described (Viacava et al, 2004) using the following primary antibodies: rat anti-mouse CD31 (dilution, 1:100; PharMingen, San Diego, CA, USA) for evaluation of microvascular density and the rabbit anti-human VEGF-A to screen VEGF as a tumour cell-associated angiogenic factor (Oncogene Research Products, Cambridge, MA, USA; dilution $1: 100)$. Negative controls were obtained by replacing the primary antibody with nonimmune serum.

Cytoplasmic staining was scored positive for VEGF-A. The degree of positivity was evaluated by calculating the percentage of immunoreactive cells on a minimum of 500 cells (Viacava et al, 2004). To calculate microvessel density, three most vascularised areas of the tumour ('hot spots') were selected and mean values obtained by counting vessels. A single microvessel was defined as a discrete cluster of cells positive for CD31 staining, with no requirement for the presence of a lumen. Microvessel counts were performed at $\times 200(\times 20$ objective lens and $\times 10$ ocular lens; $0.74 \mathrm{~mm}^{2}$ per field). All parameters were determined independently by three expert pathologists (PV, AGN and GF), and discordant cases were solved by simultaneous review.

The frozen HT-29 xenografts were collected and total RNA was isolated from the tissues using the Trizol Kit (Gibco). Human $V E G F$ and TSP-1 gene expression in tumour samples was performed by real-time PCR as described above.

Statistical analysis The analysis by ANOVA, followed by the Student-Newman-Keuls test, was used to assess the statistical differences of data in vitro and in vivo. $P$-values lower than 0.05 were considered significant. Statistical analyses were performed using the GraphPad Prism software package version 4.0 (GraphPad Software Inc., San Diego, CA, USA).

\section{RESULTS}

\section{In vitro studies}

Protracted low-dose treatment with SN-38 preferentially inhibits endothelial cell proliferation and induces apoptosis The 144-h SN-38 exposure inhibited the cell growth of HMVEC-d and HUVEC in a concentration-dependent manner (Figure 1A), and the calculated $\mathrm{IC}_{50}$ values were $0.014 \pm 0.002$ and $0.2 \pm 0.029 \mathrm{nM}$, respectively; in contrast, $\mathrm{SN}-38$ did not significantly affect the proliferation of SW620 and HT-29 cell line at low concentrations, showing much higher $\mathrm{IC}_{50}$ values $(0.64 \pm 0.014$ and 

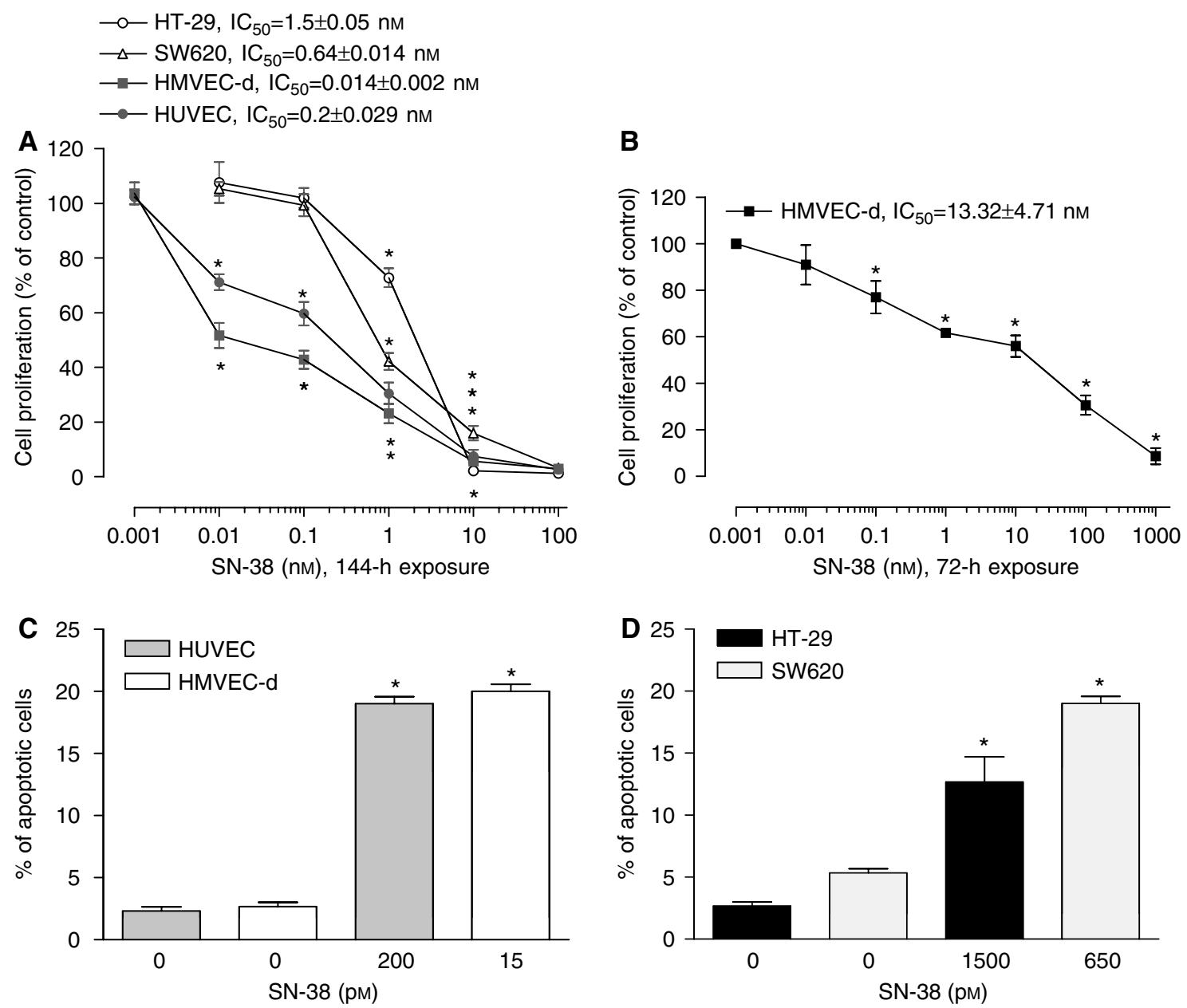

Figure I Effect of low-dose SN-38, the active metabolite of CPT-I I, on in vitro cell proliferation $(\mathbf{A}$ and $\mathbf{B})$. The antiproliferative effects of the drug were studied using prolonged continuous exposures (I 44 h) on HUVEC, HMVEC-d, HT-29 and SW620 cell lines (A) and shorter ones (72 h) on HMVEC-d cells (B). Symbols and bars, mean values \pm s.e., respectively. $* P<0.05$ vs vehicle-treated controls. $I C_{50}$, the concentration of drug that reduced cell proliferation by 50\%. Pro-apoptotic effects of $(\mathbf{C})$ SN-38 on proliferating endothelial cells treated at their experimental IC 50 (lower concentrations) for I44h and (D) SN-38 on proliferating colorectal cancer cells treated at their experimental IC 50 S (higher concentrations) for I44 h. Columns and bars, mean values \pm s.e., respectively. $* P<0.05$ vs vehicle-treated controls.

$1.5 \pm 0.05 \mathrm{~nm}$, respectively; Figure $1 \mathrm{~A})$. Furthermore, the $72-\mathrm{h}$ treatment showed a lower antiproliferative activity of SN-38 on microvascular endothelial cells $\left(\mathrm{IC}_{50} 13.3 \pm 4.71 \mathrm{~nm}\right)$, underlying a time-dependent effect (Figure 1B).

As shown in Figure 1C, after $144 \mathrm{~h}$ of treatment at their respective $\mathrm{SN}-38 \quad \mathrm{IC}_{50} \mathrm{~s}$, a significant percentage of apoptotic endothelial cells in the treated samples were found (e.g. $20 \pm 0.5$ vs $2.5 \pm 0.3 \%$ of control HMVEC-d apoptotic cells) when compared to controls. These apoptotic percentages were similar to those obtained and expected, when treating cancer cells at higher doses such as their $\mathrm{IC}_{50}$ s (Figure $1 \mathrm{D}$ ).

Simultaneous and continuous exposure of HMVEC-d cells to low concentrations of SN-38 and semaxinib for $144 \mathrm{~h}$ showed strong and moderate synergism $(\mathrm{CI}<1)$ at effect levels of 25 and $50 \%$ inhibition of cell proliferation, respectively, but an antagonistic effect for fraction affected higher than 65\% (Figure 2A). Figure 2B shows a representative isobologram of HMVEC-d cells exposed to low concentrations of SN-38 and semaxinib for $144 \mathrm{~h}$ with simultaneous and continuous exposure schedule of treatment. The position of the data point on the left of the line connecting the $\mathrm{IC}_{50}$ values of $\mathrm{SN}-38$ and semaxinib indicates synergism (Figure 2B).
Protracted low-dose treatment with SN-38 modulates expression and secretion of TSP-1 and VEGF in endothelial and cancer cells SN-38 significantly increased TSP-1 expression in both endothelial cell populations tested at their respective $\mathrm{IC}_{50} \mathrm{~s}$ and lower doses $(P<0.05$; Figure $3 \mathrm{~A}$ and $\mathrm{B})$. In particular, a $144-\mathrm{h} \mathrm{SN}$ 38 exposure at its $\mathrm{IC}_{50}$ levels resulted in a significant increase in TSP-1 expression in HMVEC-d cells $(2.49 \pm 0.12 v s 1.0$ of control expression; Figure 3A). Similar results were observed for HUVEC cells, in which TSP-1 expression was increased by SN-38 up to $1.44 \pm 0.05$ vs 1.0 of controls (Figure 3B). In contrast, TSP-1 expression in HT-29 and SW620 cancer cells was stable (Figure 3C) or decreased at low SN-38 concentrations (Figure 3D), whereas at $\mathrm{IC}_{50} \mathrm{SN}-38$ levels, it was significantly decreased when compared to controls (Figure 3C and D). Moreover, SN-38 exposure positively modulated TSP-1 protein secretion (normalised for total protein) in both the endothelial cell populations tested (Figure 3A and B), confirming the data obtained at the mRNA level. In particular, TSP-1 secretion was significantly increased up to $845 \pm 94$ and $775 \pm 74 \%$ in HMVEC-d and HUVEC cells vs $100 \%$ of controls, respectively, at the $\mathrm{IC}_{50} \mathrm{SN}-38$ concentrations (Figure $3 \mathrm{~A}$ and $\mathrm{B}$ ). Interestingly, results obtained with cancer cell cultures revealed that at SN-38 concentrations corresponding to their $\mathrm{IC}_{50} \mathrm{~s}$ and at 

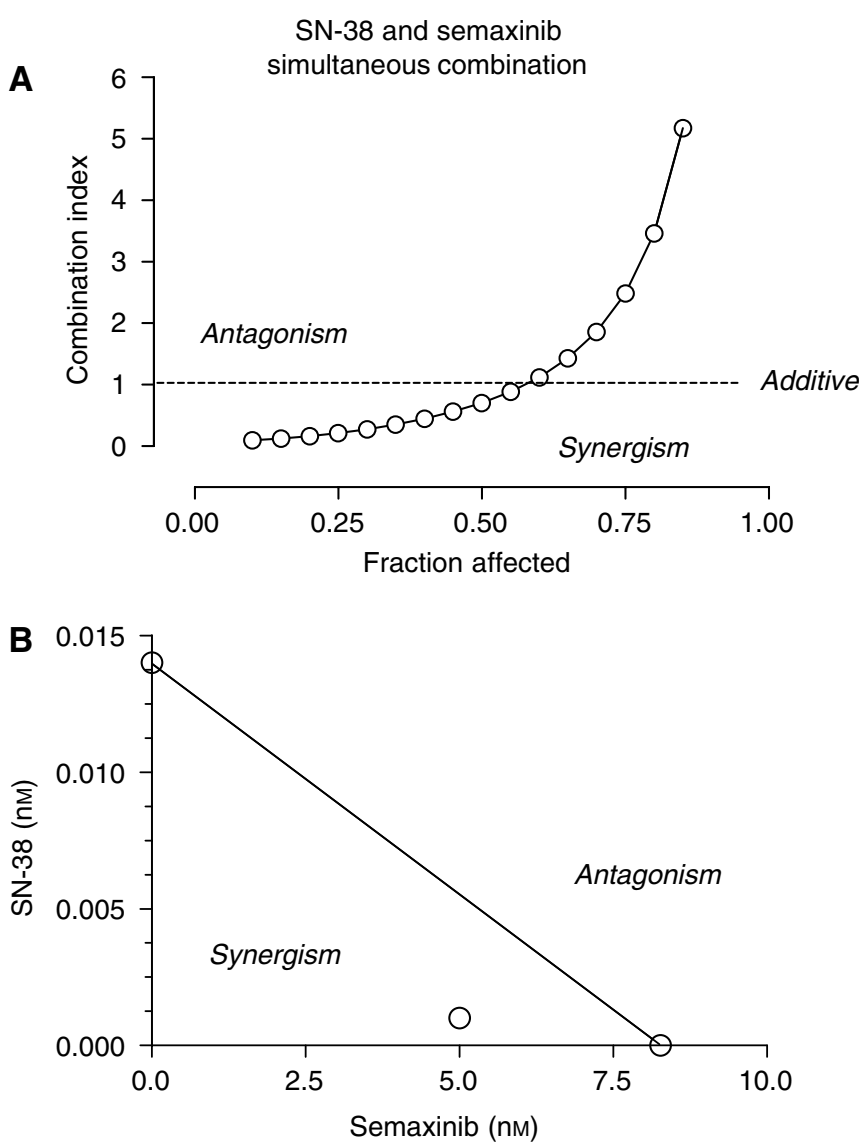

Figure 2 Combination index-fraction affected plot of semaxinib and SN-38 simultaneous | 44-h combination in HMVEC-d cells (A). Isobologram analysis of HMVEC-d cell growth inhibition by simultaneous combination of semaxinib and $\mathrm{SN}-38$ (B). The $\mathrm{IC}_{50}$ values of each drug are plotted on the axes; the solid line represents the additive effect, whereas the point representing the concentrations of semaxinib and SN-38 resulting in $50 \%$ growth inhibition of the combination is reported on the left of the connecting line, indicating synergism.

lower exposures, secreted TSP-1 was unchanged (Figure 3C) in HT-29 cells or significantly reduced (Figure 3D) up to $61.5 \pm 20 v \mathrm{~s}$ $100 \%$ of controls in SW620 cells.

The results of VEGF gene expression and protein secretion analysis showed a differential response among endothelial cell lines and colorectal cancer cells after 144-h SN-38 treatments. SN38 , at its $\mathrm{IC}_{50}$ levels, significantly increased VEGF expression both in HMVEC-d cells $(1.34 \pm 0.08$ vs 1.0 of control expression; Figure $3 \mathrm{E})$ and HUVECs (1.43 \pm 0.04 vs 1.0 of control expression; Figure $3 \mathrm{~F}$ ); only a minimal and not significant enhancement of VEGF expression was observed in HT-29 cells (Figure 3G) whereas there was a significant decrease in VEGF mRNA in SW620 cells $(0.59 \pm 0.07$ vs 1.0 of control expression; Figure $3 \mathrm{H})$. Although very low secreted levels of VEGF were measured (normalised for total protein), significant increments were observed at a $\mathrm{SN}-38$ concentration corresponding to $\mathrm{IC}_{50}$ levels in both HMVEC-d and HUVEC cell lines $(293 \pm 20$ and $369 \pm 8.5$ vs $100 \%$ of control, respectively; Figure $3 \mathrm{E}$ and F). On the contrary, VEGF secretion significantly decreased in both HT-29 cells (Figure 3G) and SW620 cells (Figure $3 \mathrm{H}$ ) at their respective $\mathrm{IC}_{50}$ concentrations.

Interestingly, shorter periods of exposure to $\mathrm{SN}-38$ (72 h) at concentrations that determined a $50 \%$ of inhibition of endothelial cell proliferation showed a significant increase of secreted TSP-1 $(P<0.05)$ in conditioned media and a weak decrease in VEGF $(P>0.05)$ (Figure $4 \mathrm{~A})$. Moreover, at the same $\mathrm{SN}-38$ dose, the phosphorylation of Akt at $\mathrm{Thr}^{308}$ resulted in significant inhibition in HMVEC-d cells (Figure 4B).

\section{In vivo studies}

Metronomic CPT-11 significantly inhibits HT-29 tumour growth in absence of toxicity HT-29 cells injected s.c. in CD nu/nu mice grew quite rapidly, and tumour masses became detectable 10 days after xenotransplantation. Tumours in control animals showed a progressive enlargement in their dimensions and an exponential growth after $\sim 20$ days; a mean volume of $\sim 3200 \mathrm{~mm}^{3}$ was reached at day 43 when the animals of the control group were killed (Figure 5A). Both MTD CPT-11 (100 $\mathrm{mg} \mathrm{kg}^{-1}$ every week) and metronomic CPT-11 ( $4 \mathrm{mg} \mathrm{kg}^{-1}$ every day) were able to inhibit tumour growth, although to a different extent, and their therapeutic effect became significant starting on the eighth and the eighteenth day, respectively after the beginning of treatments as compared to controls (Figure 5A). The MTD schedule was effective, as expected, immediately, whereas the metronomic treatment effect was delayed; however, the toxicity profiles were very different between the two treatments (see below). It is noteworthy that in the group of animals receiving the initial single high CPT-11 dose followed by a maintenance therapy with metronomic CPT-11 until the end of the study, the reduction in tumour growth was significant by day 8 compared to controls (Figure 5A) and that the tumour growth curve showed a decrease during the 50-day schedule, significantly diverging from that of controls (e.g. at day $43,383 \pm 181$ vs $3172 \pm 263 \mathrm{~mm}^{3} ; P<0.05$ ), comparable to CPT-11 MTD-treated animals, with a better response over the last 10 days of the experiment (Figure 5A).

Figure $5 \mathrm{~B}$ shows the toxicity profiles of the three different schedules. The metronomic CPT-11 treatment was favourable and acceptable with no loss of weight throughout the course of the treatment (Figure 5B) whereas the MTD CPT-11 caused a severe loss of weight that necessitated veterinary assistance with an immediate fluid therapy $\left(0.9 \%\right.$ saline, $40-80 \mathrm{ml} \mathrm{kg}^{-1}$ s.c. every $24 \mathrm{~h})$ to rescue the animals. The nadir of body weight loss was observed in the week following the first injection and the mean body weight of mice treated with doses of $100 \mathrm{mg} \mathrm{kg}^{-1}$ had returned to pretreatment values after 15 days with a continued supportive fluid therapy for the duration of the treatment (Figure 5B). However, mice treated with a single initial dose of $100 \mathrm{mg} \mathrm{kg}^{-1}$ and metronomic CPT-11 maintenance therapy recovered faster and did not require any additional fluid therapy until the end of the study (Figure 5B). Moreover, it is noteworthy that the MTD-treated animals never reached body weights similar to those treated with metronomic CPT-11 schedules.

Metronomic CPT-11 significantly decreases microvessel density and modulates VEGF and TSP-1 gene expression in HT-29 tumour tissues The s.c. injection of HT-29 colorectal cancer cells produced a tumour, the histological picture of which, after staining with haematoxylin and eosin, was consistent with colorectal adenocarcinoma (data not shown). A well-defined CD-31 immunoreactivity was localised in endothelial cells inside the control tumour mass (Figure 6A). Representative microscopic pictures showed a reduction of microvessels in the MTD CPT-11treated tumours (Figure 6C) whereas a clearly dramatic decrease of vessels in metronomic CPT-11-treated tumour samples was detected (Figure 6E and G). On the contrary, while control tumour xenografts showed a diffuse, strong and easily detectable immunoreactivity to the anti-VEGF antibody within cancer cells (Figure 6B), VEGF immunostaining weakly changed in MTDtreated samples (Figure 6D) and remained unaltered in the metronomic therapy-treated ones (Figure $6 \mathrm{~F}$ and $\mathrm{H}$ ).

To quantify the observed differences among immunoreactivity of tissue samples of different animal groups, slides were analysed for vessel count in tumour sections stained with an antibody to 

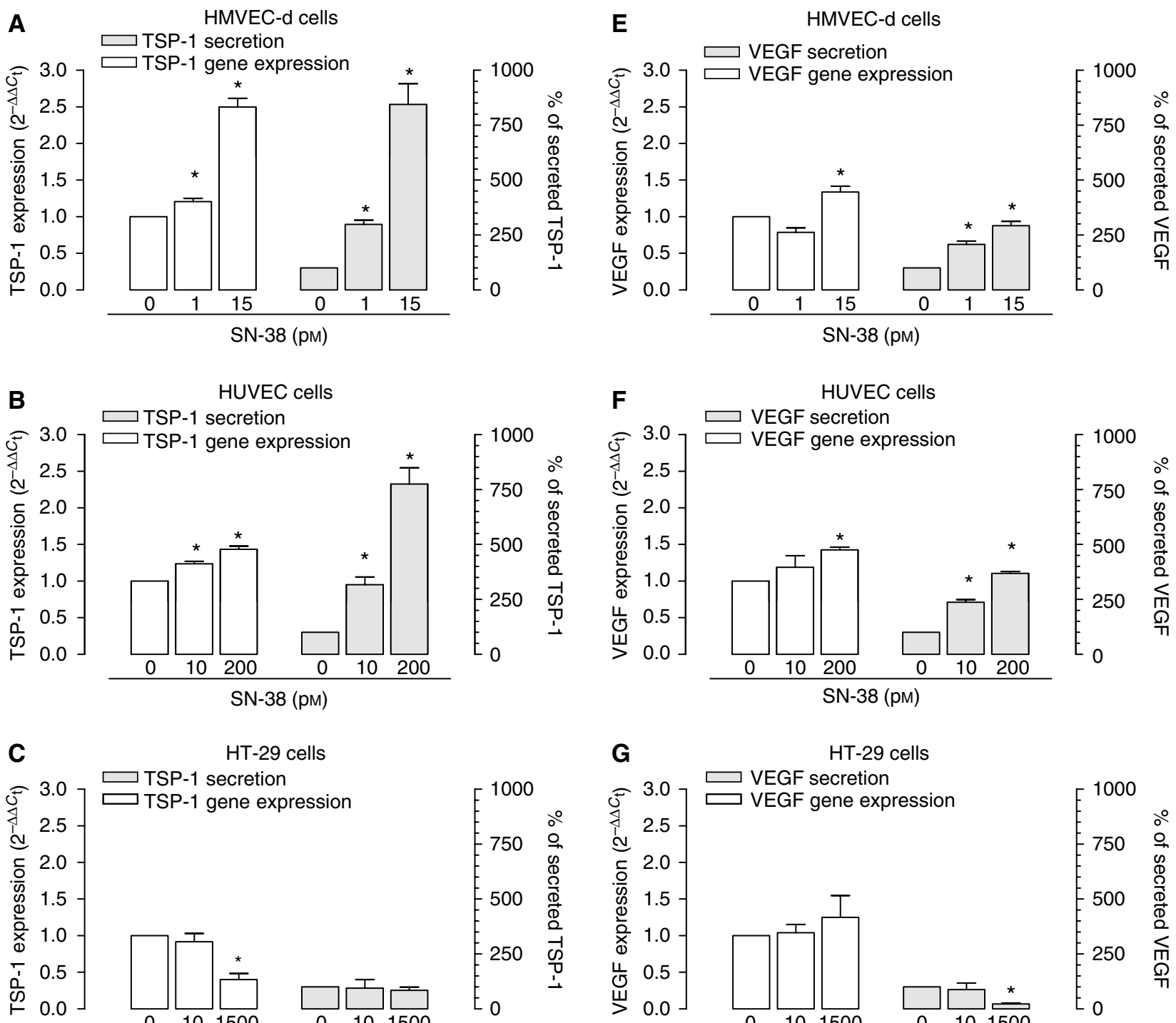

HT-29 cells
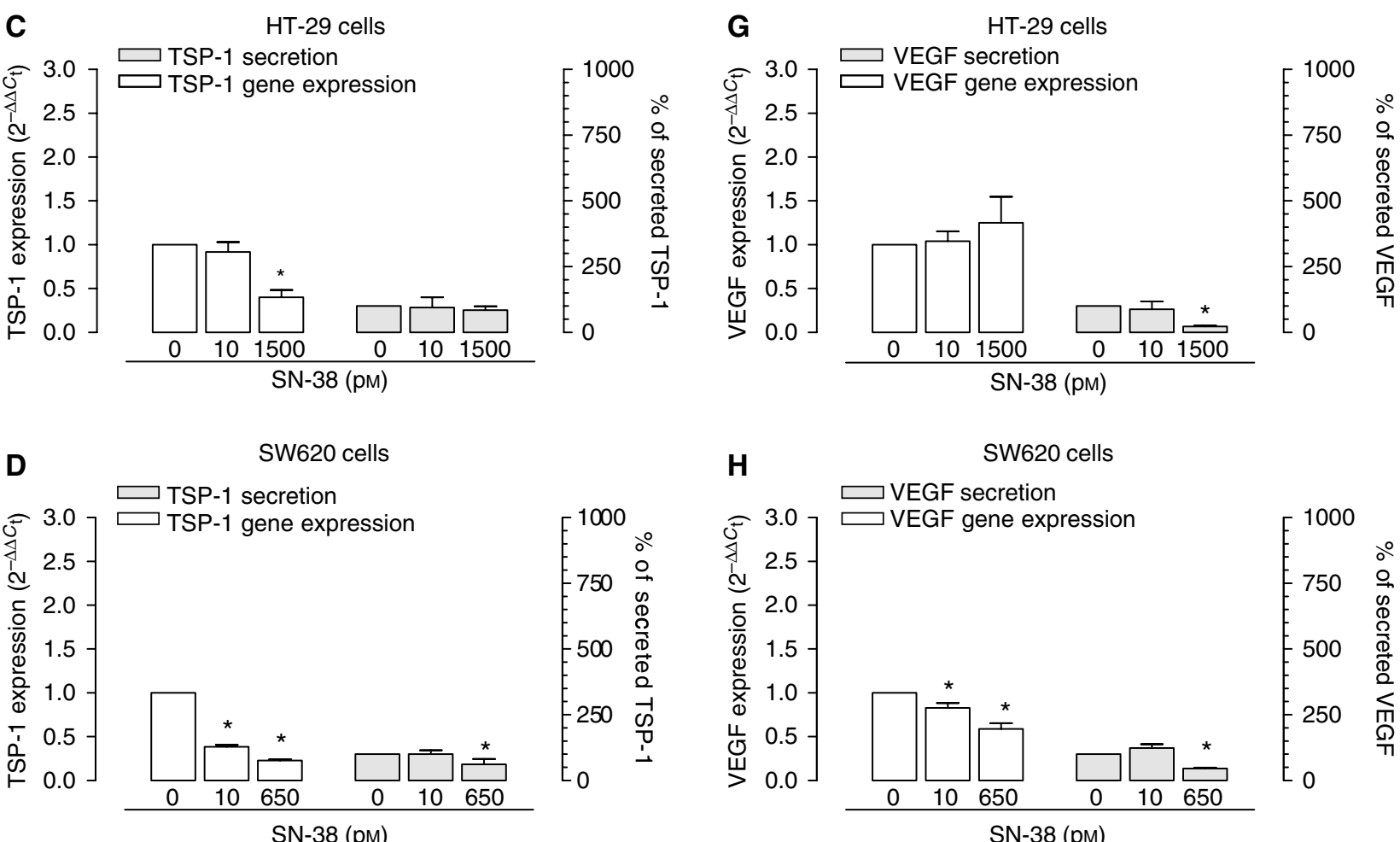

$$
\text { H }
$$

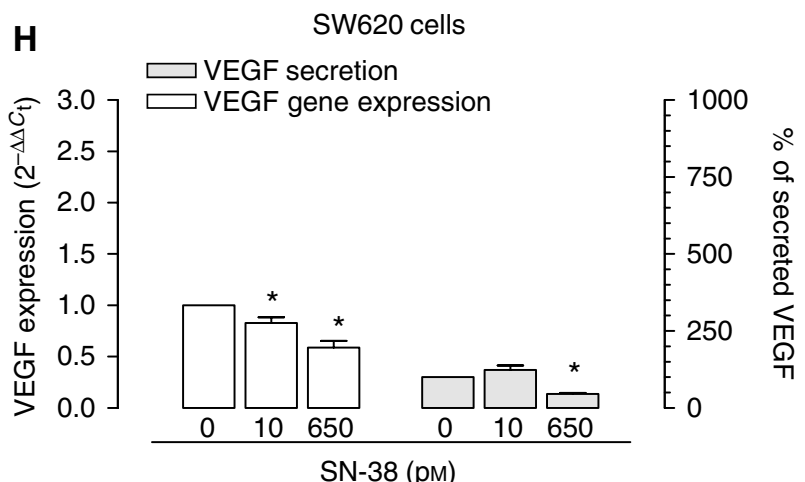

Figure 3 Thrombospondin-I (TSP-I) gene expression and secretion in HMVEC-d (A), HUVEC (B), HT-29 (C) and SW620 (D) cells exposed to SN-38 at a concentration corresponding to the experimental $I C_{50}$ of cell proliferation and at a lower and inactive concentration or with vehicle alone for $I 44 \mathrm{~h}$. Vascular endothelial growth factor (VEGF) expression and secretion in HMVEC-d (E), HUVEC (F), HT-29 (G) and SW620 (H) cells exposed to the abovementioned SN-38 concentrations. Columns and bars, mean values \pm s.e., respectively. $* P<0.05$ vs vehicle-treated controls. Thrombospondin-I and VEGF concentrations in conditioned media were measured with EIA and ELISA kits, respectively, and they were normalised to total protein concentration.

CD31. Compared with the control treatment, MTD CPT-11 treatment resulted in a significant decrease in mean vessel count $\left(25 \pm 2.1\right.$ vs $52.4 \pm 6.2$ vessels per $\mathrm{mm}^{2}$ of controls; $P<0.05$;
Figure 7A). Furthermore, both metronomic treatments $\left(4 \mathrm{mg} \mathrm{kg}^{-1}\right.$ daily and the one with the initial single $100 \mathrm{mg} \mathrm{kg}^{-1}$ dose followed by metronomic maintenance) resulted in a massive and significant 

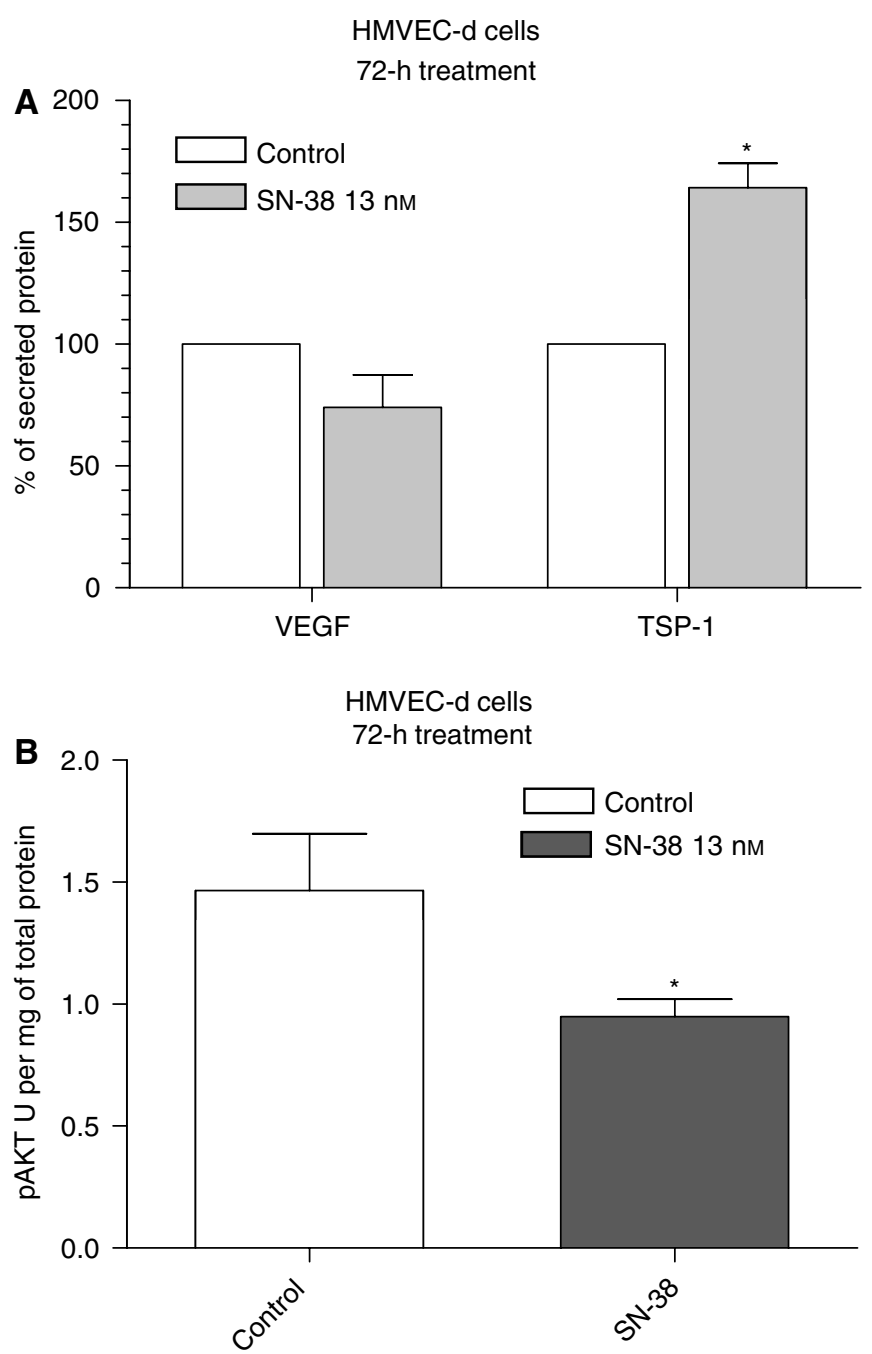

Figure 4 Thrombospondin-I (TSP-I) and VEGF secretion in HMVEC-d (A) cells exposed to $\mathrm{SN}-38$ at a concentration corresponding to the experimental $I C_{50}$ of cell proliferation or with vehicle alone for $72 \mathrm{~h}$. Thrombospondin-I and VEGF concentrations in conditioned media were normalised to total protein concentration. Modulation of Akt (pThr ${ }^{308}$ ) phosphorylation by SN-38 in HMVEC-d cells after $72 \mathrm{~h}$ of treatment (B). Columns and bars, mean values \pm s.e., respectively. $* P<0.05$ vs vehicletreated controls.

reduction in mean vessel count $(12.3 \pm 2.4$ and $8.4 \pm 2.5$ vs $52.4 \pm 6.2$ vessels per $\mathrm{mm}^{2}$ of controls, respectively; $P<0.05$ ), although there was no statistical difference between them (Figure 7A). The quantification of cancer cell VEGF immunoreactivity confirmed that there was only a weak decrease in treated groups without reaching a significant difference (Figure 7A).

Figure 7B showed the modulation of human TSP-1 and VEGF gene expression in treated tumours compared with vehicle-treated control tumours. A significant increase in both TSP-1 and VEGF expression was found in the metronomic CPT-11-treated tumours $(1.95 \pm 0.05$ and $1.62 \pm 0.04$ vs 1.0 of control expression; $P<0.05)$ whereas no significant changes were demonstrated at the MTD dose (Figure 7B). Interestingly, these results suggested a discrepancy between VEGF gene expression and VEGF protein synthesis previously shown with immunohistochemistry and between TSP-1 expression in vitro and in vivo in the HT-29 cancer cell line.
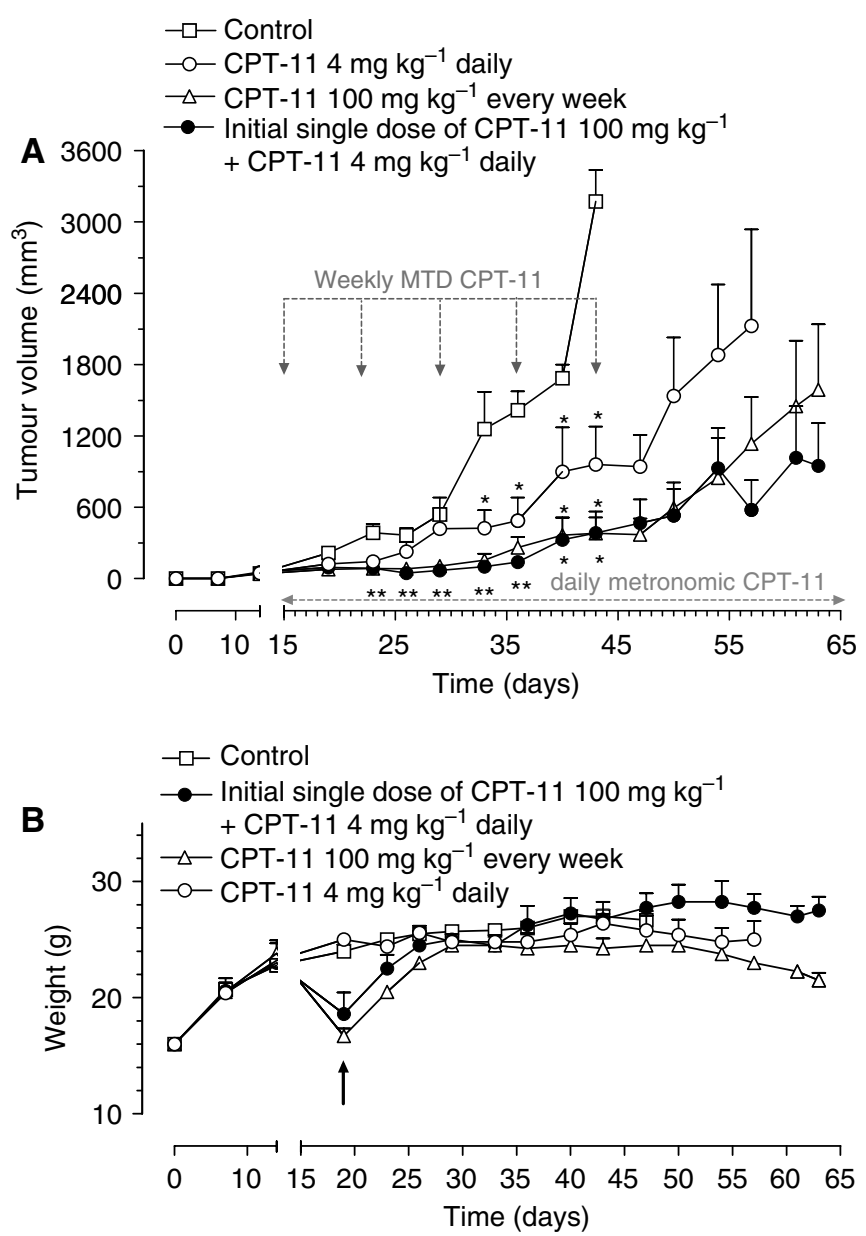

Figure 5 (A) Antitumour effect of (i) metronomic CPT-II $4 \mathrm{mg} \mathrm{kg}^{-1}$ i.p. daily, (ii) CPT-I I $100 \mathrm{mg} \mathrm{kg}^{-1}$ i.p. every week (MTD schedule) and (iii) an initial single dose of CPT-II $100 \mathrm{mg} \mathrm{kg}^{-1}$ i.p. followed by metronomic CPT-I | $4 \mathrm{mg} \mathrm{kg}^{-1}$ i.p. daily on HT-29 tumours xenotransplanted in CD nul nu mice. ${ }^{*} P<0.05$ with respect to controls. Symbols and bars, mean \pm s.e. (B) Body weight of HT-29 tumour-bearing control mice and mice treated with metronomic CPT- I I, MTD CPT-I I and the single high dose followed by the metronomic schedule. MTD CPT-I I caused a severe loss of weight that required veterinary assistance with an immediate fluid therapy $(\uparrow ; 0.9 \%$ saline, $40-80 \mathrm{ml} \mathrm{kg}^{-1}$ s.c. every $24 \mathrm{~h}$ ) to save the animals. The group of animal at MTD CPT-II needed a continued supportive fluid therapy for the duration of the treatment, whereas mice treated with a single initial dose of $100 \mathrm{mg} \mathrm{kg}^{-1}$ and metronomic maintenance did not need any additional fluid therapy until the end of the study. Symbols and bars, mean \pm s.e.

Inhibition of tumour growth in vivo by metronomic irinotecan and semaxinib A significant in vivo antitumour effect of metronomic irinotecan was detected with both the adopted schedules (Figure 8); however, the administration of the initial single higher dose of irinotecan followed by the low-dose treatment confirmed to be more effective than the low-dose treatment alone (Figure 8). The tumour growth inhibition obtained with the combination of semaxinib $10 \mathrm{mg} \mathrm{kg}^{-1}$ twice weekly and metronomic irinotecan $4 \mathrm{mg} \mathrm{kg}^{-1}$ day $^{-1}$ was almost superimposable with irinotecan alone and no statistical differences were noted (Figure 8). On the contrary, the combination of semaxinib $10 \mathrm{mg} \mathrm{kg}^{-1}$ twice weekly and the initial single dose of $100 \mathrm{mg} \mathrm{kg}^{-1}$ irinotecan followed by the $4 \mathrm{mg} \mathrm{kg}^{-1} \mathrm{day}^{-1}$ irinotecan resulted in an almost complete regression of tumour volumes ( $T / C$ value $5.53 \%$ at day 47 of the experiment; Figure 8) and it was significantly different in the last 7 days of treatment from the same metronomic irinotecan schedule given alone (Figure 8). The toxicity profile was very favourable 

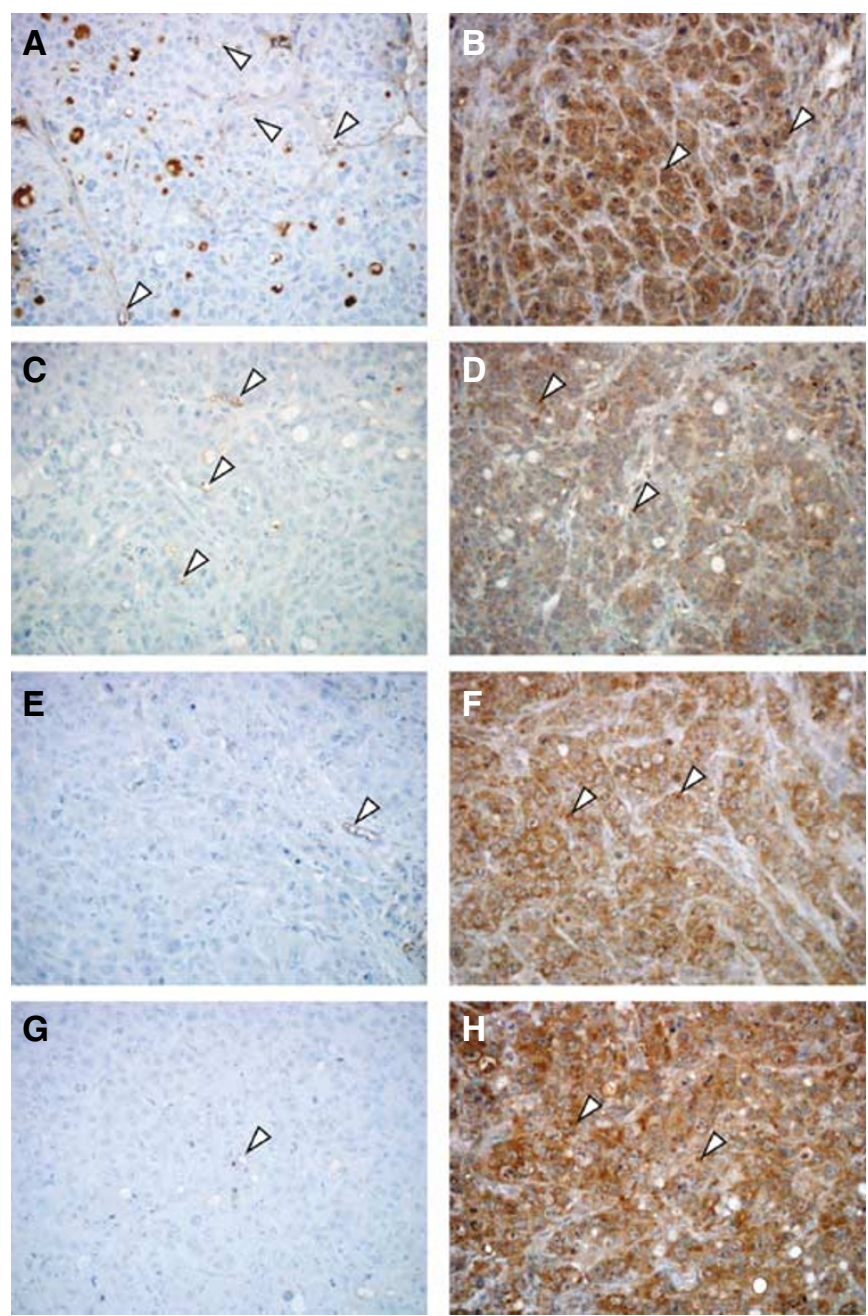

Figure 6 Representative images of immunohistochemistry of mouse CD3I and human VEGF in HT-29 xenografts in vehicle-treated mice (control group) (A and $\mathbf{B}$, respectively), in CPT-II $100 \mathrm{mg} \mathrm{kg}^{-1}$ i.p. every week (MTD schedule) group of mice (C and $\mathbf{D}$, respectively), in metronomic CPT-II $4 \mathrm{mg} \mathrm{kg}^{-1}$ i.p. daily group (E and $\mathbf{F}$, respectively) and in the group treated with an initial single dose of CPT- I I $100 \mathrm{mg} \mathrm{kg}$ i.p. followed by metronomic CPT-II $4 \mathrm{mgkg}^{-1}$ i.p. daily $(\mathbf{G}$ and $\mathbf{H}$ respectively). Arrowheads, positively stained cells. Magnification, $\times 200$.

with no differences in loss of weight throughout the course of the experiment between single and combination treatments.

\section{DISCUSSION}

Our translational study, for the first time, rationally demonstrated that low-dose metronomic irinotecan is effective in preclinical settings (in vitro and in vivo), as an antiangiogenic and antitumour schedule, modulating both TSP-1 and VEGF gene expression and secretion.

The preferential antiangiogenic and pro-apoptotic activity in vitro for protracted low concentrations of chemotherapeutic drugs has been previously demonstrated for 4-hydroperoxycyclophosphamide, taxanes, epothilones and vinblastine (Bocci et al, 2002; Klement et al, 2002) but is unclear if all or other anticancer drugs have the same properties. Usually, in vitro experiments involved a single drug exposure of between 24 and $72 \mathrm{~h}$; however, this does not mirror the in vivo situation when protracted low-dose metronomic chemotherapy protocols are administered daily. For

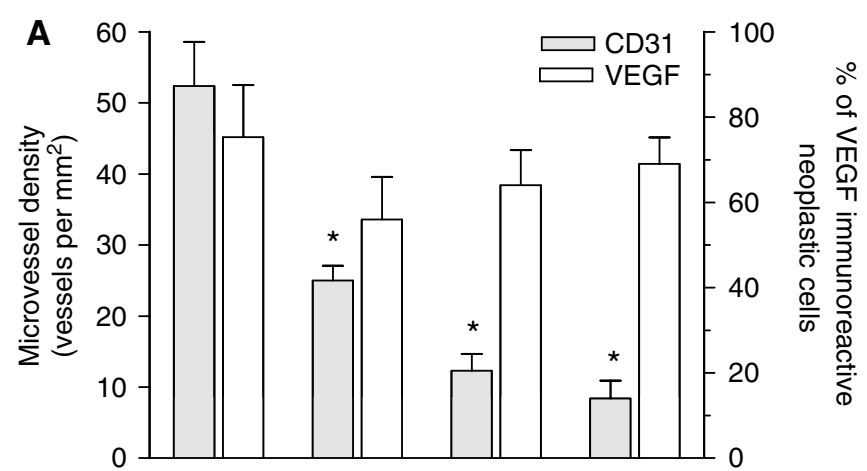

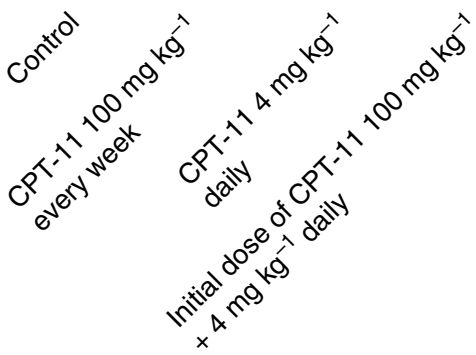

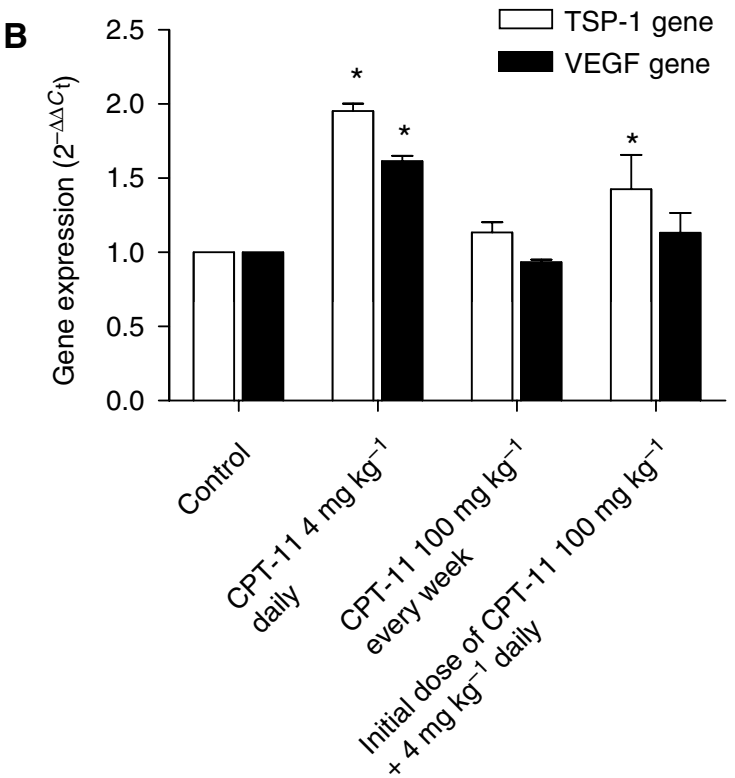

Figure 7 (A) Quantification of microvessel density and VEGF positivity in HT-29 tumour xenografts administered with MTD and metronomic CPT-II schedules. (B) Thrombospondin-I (TSP-I) and VEGF gene expression in explanted tumour samples from mice treated with MTD and metronomic CPT-II schedules. Columns and bars, mean values \pm s.e., respectively. ${ }^{*} P<0.05$ vs vehicle-treated controls.

this reason, we designed long-term in vitro assays in which human tumour cells and macrovascular or microvascular endothelial cells were exposed daily, for up to 6 days, to various low concentrations of $\mathrm{SN}-38$. Our results are highly suggestive of the presence of the so-called 'antiangiogenic window' (Bocci et al, 2002) when protracted exposure to low concentrations of $\mathrm{SN}-38$ was used. Indeed, there was a clear trend showing the effectiveness of SN-38 picomolar concentrations against endothelial cells, but not against tumour cells. This was the case not only for the inhibition of proliferation but also for the induction of apoptosis. These findings may be explained by the fact that in vitro $\mathrm{SN}-38$ 
A, initial single dose of CPT-11 $100 \mathrm{mg} \mathrm{kg}^{-1}+\mathrm{CPT}-114 \mathrm{mg} \mathrm{kg}^{-1}$ daily

B, initial single dose of CPT-11 $100 \mathrm{mg} \mathrm{kg}^{-1}+$ CPT-11 $4 \mathrm{mg} \mathrm{kg}^{-1}$ daily + semaxinib $10 \mathrm{mg} \mathrm{kg}^{-1}$ twice weekly

C, CPT-11 $4 \mathrm{mg} \mathrm{kg}^{-1}$ daily

D, CPT-11 $4 \mathrm{mg} \mathrm{kg}^{-1}$ daily + semaxinib $10 \mathrm{mg} \mathrm{kg}^{-1}$ twice weekly

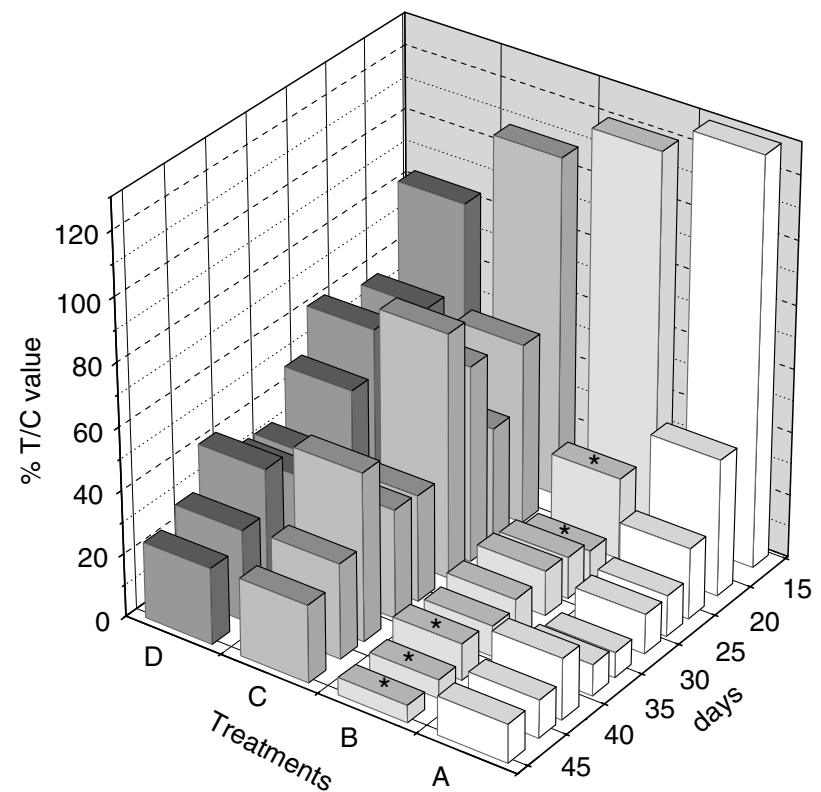

Figure 8 In vivo effects of the simultaneous combination of metronomic CPT-II schedules and semaxinib on HT-29 tumours xenotransplanted in CD nu/nu mice expressed as \% T/C value. Columns, \% T/C values. $* P<0.05$, initial single dose of CPT- I I $100 \mathrm{mg} \mathrm{kg}^{-1}$ followed by metronomic CPT- I I $4 \mathrm{mg} \mathrm{kg}^{-9}$ daily combined with semaxinib $10 \mathrm{mg} \mathrm{kg}^{-1}$ twice weekly vs initial single dose of CPT-II $100 \mathrm{mg} \mathrm{kg}^{-1}$ followed by metronomic CPT-I। $4 \mathrm{mg} \mathrm{kg}^{-1}$ daily.

protracted treatment induced a significant increase of TSP-1 expression and secretion in the conditioned media of endothelial cells at effective concentrations $\left(\mathrm{IC}_{50}\right)$. Moreover, TSP-1 has been previously described as a mediator of the specific antiangiogenic effects of this kind of therapy (Bocci et al, 2003; Damber et al, 2006), and also our results implicate this endogenous angiogenesis inhibitor as a major mediator of the low-concentration $\mathrm{SN}-38$ antiendothelial in vitro effects we studied.

Interestingly, we also observed that $\mathrm{SN}-38$ determined the significant increase of TSP-1 in conditioned medium of microvascular endothelial cells after $72 \mathrm{~h}$ of treatment, a change closer to the beginning of low-concentration therapy, and an inhibition of phosphorylation of Akt; these two observations may be mechanistically linked as demonstrated by Bussolati et al (2006), who described the modulatory role of Akt on TSP-1 synthesis in tumour endothelial cells (TEC). Indeed, the inhibition of Akt activation by administration of PI3K inhibitors significantly stimulated the synthesis and release of TSP-1 in TEC (Bussolati et al, 2006), in agreement with previous data by Niu et al (2004), who have shown that a loss of Akt signalling was related to a gradual increase in TSP-1 levels in endothelial cells.

Recently, it has been also reported that low doses of cyclophosphamide, cisplatin or docetaxel increase endothelial cell Fas receptor (Quesada et al, 2005; Yap et al, 2005). Thrombospondin-1 increases the level of Fas ligand on endothelial cells (Volpert et al, 2002; Yap et al, 2005). Moreover, it has been described that SN-38 induces Fas upregulation and caspase 8-mediated apoptosis in multiple myeloma cells (Catley et al, 2004). Thus, the low-dose SN38 may also increase Fas ligand through the increase of TSP-1 secretion and, maybe, the Fas receptor such as other low doses chemotherapeutic drugs.

Moreover, these data provided our group with the prospect of exploiting TSP-1 expression or plasma levels as pharmacodynamic markers for CPT-11 metronomic chemotherapy clinical regimens, as previously suggested by Kerbel and Kamen (2004). Low concentrations of SN-38 did not significantly change VEGF expression in cancer cells; instead, high and antiproliferative concentrations of SN-38 caused a strong inhibition of VEGF in colorectal cancer cell lines, suggesting that SN-38-mediated cytotoxic damage of cancer cells can cause a strong inhibition of VEGF secretion. Interestingly, these results are similar to those obtained by Kamiyama et al (2005) in glioma cell lines treated with high SN-38 concentrations for 24 and $48 \mathrm{~h}(0.1$ and $1 \mu \mathrm{M})$.

To proceed with the development of metronomic CPT-11, the second step was to establish the antitumour and antiangiogenic activity of this schedule in vivo. On the basis of our in vitro $\mathrm{IC}_{50}$ data (a decrease of $\sim 70 \%$ from the lowest tumour cell $\mathrm{IC}_{50}$ to the highest endothelial $\mathrm{IC}_{50}$ ) and on data from previously published studies (Allegrini et al, 2004), we decided to treat animals with an MTD regimen ( $100 \mathrm{mg} \mathrm{kg}^{-1}$ weekly), a metronomic schedule $\left(4 \mathrm{mg} \mathrm{kg}^{-1}\right.$ day $^{-1}$, i.e., a decreased total weekly dose of $\sim 70 \% v \mathrm{~s}$ the MTD schedule) and with an initial single high dose immediately followed by the metronomic regimen. The association of a bolus dose with a metronomic CPT-11 regimen was suggested by the results of Shaked et al (2005), who showed a superior antitumour activity combining intermittent high bolus doses (spaced 3-6 weeks apart) plus continuous low doses of cyclophosphamide in several tumour models, and by the work of Pietras and Hanahan (2005), who used a 'chemo-switch' regimen consisting of an initial short course of MTD cyclophosphamide, followed by long-term low-dose oral cyclophosphamide. Metronomic CPT-11 schedule was very well-tolerated, as expected from the experience with other low-dose chemotherapeutic drugs (Emmenegger et al, 2004), when compared to the MTD regimen, which required a continued supportive therapy, and significantly inhibited both tumour growth and neovascularisation. Moreover, the results suggested a superior efficacy and potent antitumour activity of the combined regimen; this enhanced activity was probably due to a direct effect of the irinotecan bolus dose on both drug-sensitive tumour cells and proliferating endothelial cells (Kerbel et al, 2000; Kamiyama et al, 2005) and a prolonged antiangiogenic effect of the metronomic regimen. Indeed, the microvessel density in tumour xenografts was markedly decreased in metronomic schedules when compared to control group and also to the MTD regimen, although to a lesser extent, confirming the data recently published by Ji et al (2007), who demonstrated an antiangiogenic effect of standard doses of CPT-11 in an orthotopic metastatic human colon cancer model in ND-GFP nude mice. A possible key role for TSP-1 in mediating some of the metronomic antiangiogenic effects of CPT-11 in vivo was suggested by the enhancement of the gene expression of the endogenous inhibitor in tumour xenografts found only in the low-dose-treated mice, whereas the VEGF immunohistochemistry analysis revealed no significant changes.

Further preclinical steps might be explored such as the combination of a targeted antiangiogenic drug, for example VEGFR-2 tyrosine kinase inhibitors, with metronomic irinotecan therapy, as such combinations show much greater antitumour efficacy compared with metronomic chemotherapy alone or the antiangiogenic drug alone (Klement et al, 2000; Kerbel and Kamen, 2004; Pietras and Hanahan, 2005). Indeed, to explore this possibility, we have associated $\mathrm{SN}-38$ and irinotecan, in vitro and in vivo respectively, with semaxinib, a VEGFR-2 tyrosine kinase inhibitor. This combination obtained a synergistic effect in vitro and enhanced the antitumour activity in vivo of the association of a bolus dose with a metronomic irinotecan regimen. No preclinical data are currently available on irinotecan and semaxinib 
combination at standard doses; however, a phase I study of escalating doses of semaxinib and irinotecan in patients with advanced colorectal cancer has been recently published, describing signs of clinical activity without significant toxicity (Hoff et al, 2006). Our data confirmed the preclinical advantage of the association between an antiangiogenic drug and metronomic chemotherapy, as also recently shown by Ma and Waxman (2008), and may improve the possibility to translate a combination therapy based on metronomic irinotecan and VEGFR tyrosine kinase inhibitors into the clinics to reduce the toxicity and enhance the antitumour effects. Indeed, Garcia et al (2008) have recently reported encouraging phase II trial results of metronomic cyclophosphamide, administered daily, in combination with bevacizumab given every 2 weeks, for treatment of recurrent ovarian cancer.

In conclusion, the clinical development of a promising irinotecan-based metronomic chemotherapy and of related pharmacodynamic markers appears possible. The actual meaning of our results is the development of a rational and less- or nonempirical strategy for metronomic irinotecan chemotherapy 'from bench to bed side'. Indeed, our study focused on and preclinically suggested possible approaches with respect to addressing the major questions regarding the clinical application of metronomic chemotherapy that relates to the actual antiangiogenic activity of the chosen chemotherapeutic drug, the dosing levels, the frequency of administration, the possible combinations with other drugs and the pharmacodynamic surrogate markers to be used. Indeed, based on our experimental data, we could suggest initiating pilot phase II clinical trials with at least these four characteristics: (i) an initial CPT-11 high dose followed by a longterm continuous infusion of irinotecan in colorectal cancer patients (including patients whose tumours are already resistant to irinotecan, but who may respond again because of the antiangiogenic effect of the metronomic schedules); (ii) the CPT11 dose level should be reduced at least $70 \%$ of the maximumtolerated total dose; (iii) the CPT-11 should be combined with a recommended dose of a VEGFR-2 tyrosine kinase inhibitor to improve the overall antitumour effects; (iv) the antiangiogenic activity could be assessed with pharmacodynamic parameters such as gene expression and plasma levels of TSP-1 and VEGF.

\section{ACKNOWLEDGEMENTS}

We thank Dr Urban Emmenegger for the helpful discussion of the manuscript, Dr Laura Ciofi and Bastianina Canu for the technical assistance and Cassandra Cheng for the excellent secretarial assistance. The present work was entirely supported by a research grant from AIRC (Associazione Italiana per la Ricerca sul Cancro) to AF.

\section{REFERENCES}

Allegrini G, Goulette FA, Darnowski JW, Calabresi P (2004) Thrombospondin-1 plus irinotecan: a novel antiangiogenic-chemotherapeutic combination that inhibits the growth of advanced human colon tumor xenografts in mice. Cancer Chemother Pharmacol 53: 261-266

Bertolini F, Paul S, Mancuso P, Monestiroli S, Gobbi A, Shaked Y, Kerbel RS (2003) Maximum tolerable dose and low-dose metronomic chemotherapy have opposite effects on the mobilization and viability of circulating endothelial progenitor cells. Cancer Res 63: 4342-4346

Bocci G, Danesi R, Marangoni G, Fioravanti A, Boggi U, Esposito I, Fasciani A, Boschi E, Campani D, Bevilacqua G, Mosca F, Del Tacca M (2004a) Antiangiogenic $v s$ cytotoxic therapeutic approaches to human pancreas cancer: an experimental study with a vascular endothelial growth factor receptor-2 tyrosine kinase inhibitor and gemcitabine. Eur J Pharmacol 498: $9-18$

Bocci G, Fioravanti A, Orlandi P, Bernardini N, Collecchi P, Del Tacca M, Danesi R (2005) Fluvastatin synergistically enhances the antiproliferative effect of gemcitabine in human pancreatic cancer MIAPaCa-2 cells. $\mathrm{Br} J$ Cancer 93: 319-330

Bocci G, Francia G, Man S, Lawler J, Kerbel RS (2003) Thrombospondin 1, a mediator of the antiangiogenic effects of low-dose metronomic chemotherapy. Proc Natl Acad Sci USA 100: 12917-12922

Bocci G, Man S, Green SK, Francia G, Ebos JM, du Manoir JM, Weinerman A, Emmenegger U, Ma L, Thorpe P, Davidoff A, Huber J, Hicklin DJ, Kerbel RS (2004b) Increased plasma vascular endothelial growth factor (VEGF) as a surrogate marker for optimal therapeutic dosing of VEGF receptor-2 monoclonal antibodies. Cancer Res 64: 6616-6625

Bocci G, Nicolaou KC, Kerbel RS (2002) Protracted low-dose effects on human endothelial cell proliferation and survival in vitro reveal a selective antiangiogenic window for various chemotherapeutic drugs. Cancer Res 62: 6938-6943

Browder T, Butterfield CE, Kraling BM, Shi B, Marshall B, O'Reilly MS, Folkman J (2000) Antiangiogenic scheduling of chemotherapy improves efficacy against experimental drug-resistant cancer. Cancer Res 60: $1878-1886$

Bussolati B, Assenzio B, Deregibus MC, Camussi G (2006) The proangiogenic phenotype of human tumor-derived endothelial cells depends on thrombospondin-1 downregulation via phosphatidylinositol 3-kinase/Akt pathway. J Mol Med 84: 852-863

Catley L, Tai YT, Shringarpure R, Burger R, Son MT, Podar K, Tassone P, Chauhan D, Hideshima T, Denis L, Richardson P, Munshi NC, Anderson KC (2004) Proteasomal degradation of topoisomerase I is preceded by cJun NH2-terminal kinase activation, Fas up-regulation, and poly(ADP- ribose) polymerase cleavage in SN38-mediated cytotoxicity against multiple myeloma. Cancer Res 64: 8746-8753

Chou TC (2006) Theoretical basis, experimental design, and computerized simulation of synergism and antagonism in drug combination studies. Pharmacol Rev 58: 621-681

Damber JE, Vallbo C, Albertsson P, Lennernas B, Norrby K (2006) The antitumour effect of low-dose continuous chemotherapy may partly be mediated by thrombospondin. Cancer Chemother Pharmacol 58: $354-360$

Di Paolo A, Bocci G, Danesi R, Del Tacca M (2006) Clinical pharmacokinetics of irinotecan-based chemotherapy in colorectal cancer patients. Curr Clin Pharmacol 1: 311-323

Emmenegger U, Man S, Shaked Y, Francia G, Wong JW, Hicklin DJ, Kerbel RS (2004) A comparative analysis of low-dose metronomic cyclophosphamide reveals absent or low-grade toxicity on tissues highly sensitive to the toxic effects of maximum tolerated dose regimens. Cancer Res 64: $3994-4000$

Garcia AA, Hirte H, Fleming G, Yang D, Tsao-Wei DD, Roman L, Groshen S, Swenson S, Markland F, Gandara D, Scudder S, Morgan R, Chen H, Lenz HJ, Oza AM (2008) Phase II clinical trial of bevacizumab and low-dose metronomic oral cyclophosphamide in recurrent ovarian cancer: a trial of the California, Chicago, and Princess margaret Hospital phase II consortia. J Clin Oncol 26: 76-82

Hamano Y, Sugimoto H, Soubasakos MA, Kieran M, Olsen BR, Lawler J, Sudhakar A, Kalluri R (2004) Thrombospondin-1 associated with tumor microenvironment contributes to low-dose cyclophosphamide-mediated endothelial all apoptosis and tumor growth suppression. Cancer Res 64: $1570-1574$

Hoff PM, Wolff RA, Bogaard K, Waldrum S, Abbruzzese JL (2006) A Phase I study of escalating doses of the tyrosine kinase inhibitor semaxanib (SU5416) in combination with irinotecan in patients with advanced colorectal carcinoma. Jpn J Clin Oncol 36: 100-103

Hsueh CT, Chiu CF, Kelsen DP, Schwartz GK (2000) Selective inhibition of cyclooxygenase-2 enhances mitomycin-C-induced apoptosis. Cancer Chemother Pharmacol 45: 389-396

Ji Y, Hayashi K, Amoh Y, Tsuji K, Yamauchi K, Yamamoto N, Tsuchiya H, Tomita K, Bouvet M, Hoffman RM (2007) The camptothecin derivative CPT-11 inhibits angiogenesis in a dual-color imageable orthotopic metastatic nude mouse model of human colon cancer. Anticancer Res 27: $713-718$

Kamiyama H, Takano S, Tsuboi K, Matsumura A (2005) Anti-angiogenic effects of SN38 (active metabolite of irinotecan): inhibition of hypoxia- 
inducible factor 1 alpha (HIF-1alpha)/vascular endothelial growth factor (VEGF) expression of glioma and growth of endothelial cells. J Cancer Res Clin Oncol 131: 205-213

Kerbel RS, Kamen BA (2004) The anti-angiogenic basis of metronomic chemotherapy. Nat Rev Cancer 4: 423-436

Kerbel RS, Viloria-Petit A, Klement G, Rak J (2000) 'Accidental' antiangiogenic drugs. anti-oncogene directed signal transduction inhibitors and conventional chemotherapeutic agents as examples. Eur J Cancer 36: $1248-1257$

Klement G, Baruchel S, Rak J, Man S, Clark K, Hicklin DJ, Bohlen P, Kerbel RS (2000) Continuous low-dose therapy with vinblastine and VEGF receptor-2 antibody induces sustained tumor regression without overt toxicity. J Clin Invest 105: R15-R24

Klement G, Huang P, Mayer B, Green SK, Man S, Bohlen P, Hicklin D, Kerbel RS (2002) Differences in therapeutic indexes of combination metronomic chemotherapy and an anti-VEGFR-2 antibody in multidrugresistant human breast cancer xenografts. Clin Cancer Res 8: 221-232

Ma J, Waxman DJ (2008) Modulation of the antitumor activity of metronomic cyclophosphamide by the angiogenesis inhibitor axitinib. Mol Cancer Ther 7: 79-89

Man S, Bocci G, Francia G, Green SK, Jothy S, Hanahan D, Bohlen P, Hicklin DJ, Bergers G, Kerbel RS (2002) Antitumor effects in mice of low-dose (metronomic) cyclophosphamide administered continuously through the drinking water. Cancer Res 62: 2731-2735

Niu Q, Perruzzi C, Voskas D, Lawler J, Dumont DJ, Benjamin LE (2004) Inhibition of Tie-2 signaling induces endothelial cell apoptosis, decreases Akt signaling, and induces endothelial cell expression of the endogenous anti-angiogenic molecule, thrombospondin-1. Cancer Biol Ther 3: $402-405$

O'Leary JJ, Shapiro RL, Ren CJ, Chuang N, Cohen HW, Potmesil M (1999) Antiangiogenic effects of camptothecin analogues 9-amino-20(S)-camptothecin, topotecan, and CPT-11 studied in the mouse cornea model. Clin Cancer Res 5: $181-187$
Pietras K, Hanahan D (2005) A multitargeted, metronomic, and maximumtolerated dose 'chemo-switch' regimen is antiangiogenic, producing objective responses and survival benefit in a mouse model of cancer. $J$ Clin Oncol 23: 939-952

Quesada AJ, Nelius T, Yap R, Zaichuk TA, Alfranca A, Filleur S, Volpert OV, Redondo JM (2005) In vivo upregulation of CD95 and CD95L causes synergistic inhibition of angiogenesis by TSP1 peptide and metronomic doxorubicin treatment. Cell Death Differ 12: 649-658

Shaked Y, Emmenegger U, Francia G, Chen L, Lee CR, Man S, Paraghamian A, Ben-David Y, Kerbel RS (2005) Low-dose metronomic combined with intermittent bolus-dose cyclophosphamide is an effective long-term chemotherapy treatment strategy. Cancer Res 65: 7045-7051

Sund M, Zeisberg M, Kalluri R (2005) Endogenous stimulators and inhibitors of angiogenesis in gastrointestinal cancers: basic science to clinical application. Gastroenterology 129: 2076-2091

Tahir SK, Nukkala MA, Zielinski Mozny NA, Credo RB, Warner RB, Li Q, Woods KW, Claiborne A, Gwaltney II SL, Frost DJ, Sham HL, Rosenberg SH, Ng SC (2003) Biological activity of A-289099: an orally active tubulin-binding indolyloxazoline derivative. Mol Cancer Ther 2: $227-233$

Viacava P, Naccarato AG, Bocci G, Fanelli G, Aretini P, Lonobile A, Evangelista G, Montruccoli G, Bevilacqua G (2004) Angiogenesis and VEGF expression in pre-invasive lesions of the human breast. J Pathol 204: 140 - 146

Volpert OV, Zaichuk T, Zhou W, Reiher F, Ferguson TA, Stuart PM, Amin M, Bouck NP (2002) Inducer-stimulated Fas targets activated endothelium for destruction by anti-angiogenic thrombospondin-1 and pigment epithelium-derived factor. Nat Med 8: 349-357

Yap R, Veliceasa D, Emmenegger U, Kerbel RS, McKay LM, Henkin J, Volpert OV (2005) Metronomic low-dose chemotherapy boosts CD95dependent antiangiogenic effect of the thrombospondin peptide ABT-510: a complementation antiangiogenic strategy. Clin Cancer Res 11: $6678-6685$ 